Institutional settings and changes of common pool resources in an agro-industrial food system: An anthropological study of Export horticulture in Northwest Mount Kenya

\author{
Mariah $\operatorname{Ngutu}^{1 *}$ \\ Salome Bukachi ${ }^{1}$ \\ Charles Owuor Olungah ${ }^{1}$
}

Tobias Haller ${ }^{2}$

1. Institute of Anthropology, gender and African Studies (IAGAS), University of Nairobi, Kenya

2. Institute of Social Anthropology, University of Bern, Switzerland

*Corresponding Author Email: mngutu@students.uonbi.ac.ke

Address: Institute of Anthropology, gender and African Studies (IAGAS), University of Nairobi P.O.Box 30197-00100, Nairobi, Kenya

\title{
Conflicts of interest: none
}

\begin{abstract}
Agriculture is the backbone of Kenya's economy, supporting up to $80 \%$ of the rural livelihoods. Kenya's export horticulture is currently the leading Agriculture subsector in Kenya has evolved from small-holder farming to agro-industrial large-scale export farming dominated by multinational companies. It is regarded as an agro-industrial food system based on the economies of scale producing for mass markets outside of the production area. Much of the food consumed from this food system has undergone multiple transformations and been subject to a host of formal and informal insitutions (rules, regulations, standards, norms and values). An Anthropological study of export horticulture in Northwest Mount Kenya was carried out utilizing qualitative data collection methods in Northwest Mount Kenya region. Data was coded and analysed thematically based on grounded theory approach. The study described the institutional settings of export horticulture from an emic perspective as changing and defining the operations of the food system access and management of common pool resources, namely water and land. With the agro-industrial food system competing for these scarce resources in a semi-arid zone, there is potential for conflict and also reduced production and overall benefits to the different actors in the study area.
\end{abstract}

Key words: An anthropological study; agro-industrial food system; institutional settings; formal and informal institutions; export horticulture; common pool resources 


\section{Introduction}

Globally, over 70 percent of the poor in developing countries live in rural areas where they depend on agriculture to sustain their livelihoods. Just like other developing Sub Saharan Africa, agriculture is the backbone of Kenya's economy, supporting up to $80 \%$ of the rural livelihoods (GoK, 2017; FAO 2016) . Kenya's export horticulture is regarded as an agroindustrial food system based on the economies of scale producing for mass markets outside of the production area(Colonna et al., 2013). Much of the food consumed from this food system has undergone multiple transformations, travelled substantial distances, passed through different hands and been subject to subject to a host of formal and informal insitutions (rules, regulations, standards, norms and values) (Henson and Humphrey, 2010; Colonna et al., 2013; Haller et al., 2013).

The horticulture sector which is currently the leading Agriculture subsector in Kenya has evolved from small-holder farming to agro-industrial large-scale export farming dominated by multinational companies (Colonna et al 2013; GoK, 2014). There are also small-holder farmers producing as out-growers for the export companies and others for the domestic markets (Ongeri 2014; Ulrich 2014). The sector's production of vegetables, fruits and high care products is market driven with increasingly stringent food safety standards resulting from consumer awareness and a series of food safety failures in the 1990s ( MacGregor et al 2014). Institutions such as international food safety standards now play a vital role in the sector as there are mandatory certifications and standards to be adhered to in light of the environment, workforce and food safety ( Ouma 2010; MacGregor et al 2014).

Despite the stringent standards, the consumer-led demand for these products has been increasing steadily in the last three decades with Kenya's value of horticultural products quadrupling within this period.

Today horticulture is Kenya's largest single source of export earnings employing an estimated 4.5 million people in production and processing(CARE 2016; GoK 2017). The 
increased production in Kenya from the rising market demand of horticultural products has caused the sector to spread beyond the mountainous high yielding areas into arid zones often prone to resource contestation (Schuler 2004; Ulrich 2014; Lanari et al 2016). Studies on horticulture in Kenya and other African countries including Senegal reported both positive and detrimental effects of this sector to development and livelihoods ( Dolan and Humphrey 2000; Asfaw et al 2010; Ongeri 2014; CARE 2016).

Export horticulture, when regarded as an agro-industrial food system producing for commercial markets outside of the production area thus, needs to be interrogated further in relation to sustainable food systems and ecological considerations and resource use (Colonna et al 2013). There are institutions ('rules of the game') in export horticulture that define the institutional setting for access to resources and production (Haller et al., 2013). As export horticulture rises in financial importance and becomes more valuable it impacts on the local institutional setting of working conditions, property rights and access to common pool resources such as water and pasture vital for local livelihoods (Haller et al 2013; Ensminger 1998). The important research question for this study is if the institutional settings and changes of agro-industrial food system has a critical impact on other food systems and their viability in a semi-arid zone when weighted against overall effects on common pool resource use and management?

This paper focuses on export horticulture investments in a semi-arid zone of Northwest Mount Kenya. It relates to research on large-scale land acquisitions or land grabbing debates by focusing on an institutional analysis that studies the impact on access to common pool resources (water and pasture).

\section{Results}

\section{Land tenure, use and access in Northwest Mount Kenya region}


In pre-colonial Kenya land the Northwest Mount Kenya extending into the Rift valley region was mainly owned by pastoral communities as community lands where water, land and pasture were utilized communally. When Kenya became a British colony lands in these region were taken up by the white settlers alongside the Nyandarua ranges and regarded as White Highlands. At this time the pastoral communities were pushed away into Mugogodo forest area. The White settlers had casual workers in their farms and establishments who were mainly from the Agikuyu and Ameru communities. As the colonial era came to an end in the late 1950 s into early 1960 s, the settlers begun to leave the colony back to Britain and hence disposed of their properties and lands.

Actors around the study setting explain the land tenure use and access overtime differently. One explanation is that the White settlers overtime sold their land to their workers who paid up through portions of their salaries to acquire shares of the land / property and took up ownership after the settlers left. The second explanation is that there was a group of affluent individuals mainly from the Agikuyu community who had some money topped it up with loans from the Agricultural Finance Cooperation to acquire the property in this region once it was up for sale by the White settlers.

The third explanation is that when Kenya became an independent nation the first president was from the Agikuyu community and some of his close affiliates benefited from his power position as they were gifted property and land which initially belonged to white settlers including some in North West Mount Kenya region as in the excerpts:

[And all that land was bought from Mugambi?] Yes. It all belonged to Mugambi. It was very big. Half of Muramati belongs to him. He bought very many shares from the white man. No, they were a group. [Okay, a group? Then they left the land to the Africans who had shares?] You know, some Africans refused to contribute for the shares. It was not compulsory. If you wanted to get the shares, that was okay. Then when the Europeans were leaving, they would leave the farm to the Africans who had shares in the land. Even if the land was 2000 acres, 1000 acres, they just left the land to them (Village elder, Northwest Mount Kenya, KII_08) 
The Maasai who are the Ndorobos now, since they claim it is their ancestral land. There were big farms, which were owned by the white settlers. After the independence, the government had to remove these people from the lands. They reclaimed the land, by selling those lands to Africans who are able to buy the land. We have a group of kikuyus from Nyeri and Karatina and elsewhere. Who were able, who were settled there and acquired loans from AFC and bought some pieces of land in those areas of Kimangandura, and they took loans, they paid for the land. They sub-divided the land for themselves as they were tycoon (Local administration, Northwest Mount Kenya, KII0_10).

These varying explanations can only be debated based on the different actor perspectives. However, in the Northwest Mount Kenya region land at one point in pre-colonial era was communally owned and belonged to the pastoral communities. In independent Kenya land was mainly secured by the different actors on free hold titles obtained through purchase of the property from private owners. The new land owners utilized land and related resources for economic activities such as small-holder agriculture; large-scale export oriented horticulture as in the case of the farm; real estate development; private ranching and wild life conservancies.

The land, on which the export horticulture investment was located, was initially owned by one individual who had amassed large tracts of land and invested heavily in real estate in the region. The farm was acquired by its exporting company through purchase and currently is owned under the free hold land tenure. The title deeds were issued by Ministry of lands in line with the Kenya Land Act (2007). A few people leased land and acquired user rights for food productions from owners.

Communities linked to the export horticulture investment as identified in this study included those neighbouring the horticulture farm. These communities comprised people of different ethnicities originated from the study area with other who migrated into the region in search of work, pasture and livelihood opportunities.

Besides the horticulture farm, there are development companies that are constructing property as well as smaller farms doing horticulture as well as permaculture in the study area. People 
were able to get casual employment for construction, clearing fields and even farming in these other establishments. There were a few small holder farmers in this area as well who mostly teamed into farmer groups and engaged for horticulture farms in Northwest Mount Kenya.

The pastoral communities lived more towards the Northern part of the region where they were settled by government in community trust lands and land and pasture use and access is communal. There were some pastoralists who had come from Naibor and Doldol and bought land and settled around the horticulture farm's surrounding. These pastoralists still had their herds in the group ranches back in Naibor and DolDol. They engaged herders and members of their larger families to look after them and from time to time visit to tend after them. These varying land tenure arrangements were as illustrated by the different actors in the excerpts;

There were very few people in this area when the horticulture farm was beginning. People have increased with time after the farm was established. Now it is a big village. Other Europeans also started to buy land and we get construction jobs in those farms (Male Community FGD_02,)

The British army once they retire from the army they buy lands here and they settle. They build roads there, they drill boreholes then they make a living out of that. Small growers have also come up because we are getting produce from the outgrowers who are around the farm so that some were working here; they went out and started doing their work (Management, Export horticulture investment, KII_01).

You can't build in a land that is not yours. So they have bought the land and they have their own title deeds. Only that family can build on that land (Male Community FGD_01).

Given that the private property land tenure was familiar to the communities linked to the horticulture there was generally a peaceful co-existence in the area. The community rarely invaded the farm due to existing understandings that it was private property and there were legal consequences to trespass.

The investor had also instituted informal arrangements for especially the pastoral communities to access pasture in the uncultivated section of the farm alongside other community development activities through the company's corporate social responsibility. 
There so far was only one farm- community conflict over land that happened in 2006 . The investor initiated a litigation process against a community member and after years of a long and tedious lawsuit the community elders intervened and there was an out of court settlement where they called a truce.

These institutional settings around land in the study area are founded on historic entitlements and laws on land ownership. While individual owners buy and own land in the formal arrangements, pastoral communities have a historic claim on land. They perceive access rights as passed down as these were their ancestral lands wrongfully taken for them. With the erratic rainfall in the semi-arid lands there is periodic drought where pastures are scarce. In those seasons given the unequal distribution of gains from land there is potential for conflict especially between large-scale land investors such as the export horticulture investment, and communities linked to it by virtue of location. This discourse on potential conflicts is further advanced in the following section that presents the institutional settings of access and use of water.

\section{Institutional settings and changes of water use and access as a common pool resource}

Water was an important factor to consider in export horticulture production, given the waterintensity of the crops grown in this sector. The export horticulture investment relied in river water, boreholes and rainfall to access water for irrigation and domestic use within its premises. As it accessed water, the farm shared this resource with other users including smallholder farmers, other horticulture establishments and pastoralists (as in figure 3.1-map of the study area) as it was located downstream of the Ewaso Ng'iro River basin. The use and regulation of water in the region was by Water Resources Authority (WRA) which worked through Community led Water Resource Users Associations (WRUAs) to regulate river water users. The horticulture investment was in two WRUAs given it location, namely 
Ontilili and Timau. WRA had structures in place including water meters in farms to record the cubic meters of water utilized for monthly payments.

At the County, the Nanyuki Water and Sewerage Company (NAWASCO) offered tapped water services payable monthly to supplement water for domestic use mainly from the boreholes and rainwater harvested in the horticulture farms and large-scale ranches in the region. The excerpts from focus group discussants detailed these access and use of water dynamics:

But there are people from the water authority who monitor that water even as you pump it. Because like now, the water is not enough, pumping river water is regulated because some people may not get water. Sometimes those people can even carry your generator (Male Community FGD_01)

If your farm goes up to the river, 10ft towards the river belongs to the government. So even if your farm goes all the way to the river, you are not allowed to farm very close to the river. So what you do is put pipes and pump water from the river using a generator right to your farm (Male Community FGD_01).

\section{Resource contestation linked to water scarcity}

The horticulture farm regarded its downstream location coupled with the erratic rainfall patterns in this leeward side of Mount Kenya with the semi-arid climate as the main challenge in accessing water for irrigation. There was increased river water use upstream with 2 main rivers now turning seasonal. In spite of the erratic rainfalls, downstream users argued that river water would still be available and enough if it was properly regulated and coordinated. Not all river water users were registered and there was therefore the possibility of many users beyond the river's capacity. Users upstream were also blamed to excess abstraction of water limiting the access by the downstream users. These varying perspectives on the water scarcity were as elaborated by the different actors in the excerpts:

But you see now these local WRA officials are not being honest. So when someone goes to the head office asking for the additional water points, you get one and you can see from their system there aren't many users authorized to access the water. However, in practical there are so many other users and we don't know whether they are allowed or not (Management, Horticulture farm, North West Mount Kenya, KII_02) 
Because the horticulture farms tamper with the meter and that is not something that is hidden. They use huge meters that abstract most of the water, then they release water that has been contaminated with chemicals (Small holder farmer, North West Mount Kenya, IDI_33)

Even when it is dry, the river has water. Another horticulture farm [H] has closed this water. They are the ones who have closed it. You know they grow flowers, and the demand for flowers is big because of weddings and all that. .... H is a very big company. When we complain, we are just locals, those are big people. If they give a bribe of say 3 million, we can't compete with that? Sometimes even when we complain, we are told it will be opened, when we come back home, there's no water, or they open it for some time then close it again... (Female community FGD_03)

Other food producers including subsistence farmers, pastoralists and outgrowers in the study area were also affected largely by the perennial water shortages in the arid and semi-arid zone with erratic rainfall patterns. The communities depended on the river water for irrigation farming, watering livestock and for domestic use including drinking and cooking in instances where access to borehole and tapped water was limited. Interestingly, during the periods that the export horticulture investment faced reduced production because of water scarcity, the outgrowers in the study area were not able to produce and meet projected targets. At such times then the exporting company had to rely on outgrowers outside of the study area to supply produce demands. Access to pasture for the cattle and livestock reared by the pastoral communities within this region was also challenged by the scarce water resources as in the excerpt as voiced by FGD discussants:

There are pastoralists, and there are farmers, those who like to grow crops and our main problem is water. If we had enough water, then we would grow more crops but because of water scarcity, farming becomes difficult. Some time ago, the river never dried up, because people in this area were not really farmers. Most of the ones who practiced farming were from around Timau coming this way [downstream the Ewaso $\mathrm{Ng}$ 'iro basin]. Now since the farmers increased in this area and establishment of the large farms like the horticulture farms that practice large-scale farming in that upper area, the water levels in the river were affected (Female Community FGD_03)

Large investments dealt with the water scarcity in the Northwest Mount Kenya region by

investing in boreholes and manmade dams within their settings to supplement the diminishing river water. The export horticulture farm had 2 boreholes and dams with a capacity of 1.5

million cubic meters of water. However this wasn't sufficient to meet their water needs and in the period of water scarcity the investment lost many crops that could not be watered and had 
to depend on other sources to supplement their market supplies for the season between December, 2016 and late March, 2017 when the rains started.

The export horticulture investment was at the time of the study expanding the existing dam coverage to extend to about 2 million cubic meters water holding capacity. In seasons of scarcity the water reservoirs of large-scale land investments such as the horticulture farms were barely enough and sharing with other user was limited to special arrangements. For instance the study site farm provided free water to the school and police station as part of CSR. Other establishments offered borehole water to the communities at a cost of Kshs 20.00(0.20 USD) per 20 litre jerrican. This commodification of water only made access by users a challenging aspect.

Additionally, the communities around the river especially those downstream faced the threat of using contaminated water redirected from the large-scale horticulture farms. The farms used large amount of chemicals for pest management and often when not monitored would dispose of the waste inappropriately. The chemical waste would end up mixing with the flowing river water which other food producers accessed for domestic and subsistence. Water likely contaminated with pesticides and fertilizer residue from horticulture farming was therefore a threat to human and animal health and the environment in the study area as illustrated in the excerpts:

There was a time locals were drinking dirty water. The water in the river was contaminated by water from the pack-house. There was a problem and I think they had not realized it. And you know one can't tell dirty water when it's flowing in the river because the soil purifies that water. When the horticulture farm realized the mistake, it seems their pipes were faulty, they constructed that dam you are seeing there (Female Community FGD_03)

In addition to water abstraction, the communities along the river, and downstream take this water contaminated by chemicals from the big horticulture farms...I remember at some point in there was a huge demonstration by the all the people from Isiolo and Laikipia, the pastoral communities that are there because this Ewaso $\mathrm{Ng}$ 'iro River is their lifeline as there is no other river so (Small holder farmer, IDI_27) 
The drying up of the two rivers, the limited options for alternative water for most users, the possible contamination of water and the unresolved river water issues fuelled by the ideologies of different actors on their ownership and access, posed as a platform for conflicts over water as a common pool resource.

For instance, pastoralists in search of pasture and water could trespass into privately owned properties including large-scale horticulture farms creating potential for resource related conflicts. In the study area these resource related conflicts were witnessed in 2017 with herders invading private large-scale ranches to access water and pasture for their livestock. The horticulture farm wasn't directly affected by these conflicts as the herders targeted ranches rearing livestock and conserving wildlife. However, data collection this study was concluded as this pastoralist - private ranches conflict was developing. Detailed studies to explore the contentious issues around water and land as shared resources in Northwest Mount Kenya are recommended.

\section{Discussion}

Notably, Kenya's export horticulture production driven by rising global demands has expanded beyond the 'traditional' mountainous high yielding areas into arid and semi-arid (ASALs) zones. The ASALs such as the Northwest Mount Kenya region are often prone to common pool resources (CPR) contestation among the different food systems given the poor rainfall and frequent dry spells (GOK, 2013; Ulrich, 2014). The region's different food systems compete for land, capital, and water, with access to water being particularly hotly contested (Lanari et al.,, 2016; Letai, 2011). Despite arid climatic conditions in Northwest Mount Kenya, the horticulture sector is booming with over 30 horticulture companies in 35 farms competing against other food systems in the region for the already scarce resources. (Lanari, 2014; Lanari et al.,2016; Ulrich, 2014; Zaehringer et al., 2018) 
Developments in export horticulture in Kenya can be related to the issue of changes in relative prices as in the institutional analysis model of Ensminger (1998). The rise of market prices for horticulture products triggers investments and changes actors' access to labor, bargaining power and institutional settings as land and other common pool resources are much more devoted to this sector (Ensminger, 1992). Further, from existing literature export horticulture is seen as one of the bright spots of African development as it has raised production standards in agriculture; created supporting industries, and provided considerable employment in rural areas (Ongeri, 2014; Dolan and Humphrey, 2000). However, critiques argue that increased globalization in export horticulture does not benefit the poor (Asfaw et al., 2010; Maertens et al., 2012).

As in the findings, the agro-industrial system dominates the institutional setting and control over resources via private property rights, but it ideologically legitimizes their operation with modernity that the investment brings with the narrative of poverty in the area and the discourse of development that it brings. This acts as an Anti-politics Machine that hides that the government is not willing or cannot provide basic services and that the company will bring betterment with the government handing over land and vital CPRs to them (Ferguson, 1994).

It hides the vulnerability and the short term duration of such operations as well as the lack of bargaining power local households and especially poorer segments and women have to secure income from these new operations. It might be that people try to get cash for short term which they invest in other activities. However this will only be possible on small scale for poorer households as the monetization of life eats up most of the cash earned easily, while later on access to the commons is lost. For outgrowers who might get indebted via their operations there is well the danger to lose their land. Large-scale land investments such as export horticulture often emphasize the rapid increase in yield they can produce and the 
additional employment they can provide. However, these additional opportunities of agricultural production are not felt locally or only on a short term basis (Zaehringer et al 2018;Ali and Kapoor, 2008; Anseeuw et al 2011; Asfaw et al 2010 ). There is also an ongoing debate on the local to national impacts of large scale land acquisitions (LSLAs) for export oriented horticulture. The growing demand for food such as the export fruits and vegetables and non-food crops, fuel and other raw materials are seen as the main drivers of these LSLAs (Borras et al., 2011, De Schutter, 2011).

As such the utilization by the agro-industrial food system and management of common pool resources such as water and land tenure poses a threat for conflicts with other food systems competing for the same resource. The resource linked conflict arising from the competition for land and water for food scarcity in the arid and semi-arid region where export horticulture is growing needs further examination to outline sustainable and equitable distribution of the CPRs. There is also possibility of disruption of production in seasons of scarcity.

Here the concept of institutions as fit turning to misfit and then to fit again is experienced as the formal and informal rules of the game are influenced to change to meet the different actors bargaining power for taking part in the food system (Haller et al 2013). All these interactions are manifested in the distributional effect and socio-economic behavior of export-oriented horticulture linked actors and in a cyclic effect manifest in the environment, population and technology aspects that influence the relative prices in this global value chain. The emerging issues in institutional settings and changes in export horticulture are crucial to the viability of the sector as an agro-industrial food system in the food security and sustainability discourses in the local context. 


\section{Materials and Methods}

\section{Description of study area}

This exploratory study targeted an export horticulture investment located in Northwest Mount Kenya region, downstream of the Ewaso Ng'iro North Basin, within Muramati Location of Laikipia County, with out-grower farmers in Meru County and Nyeri County (Map 1).

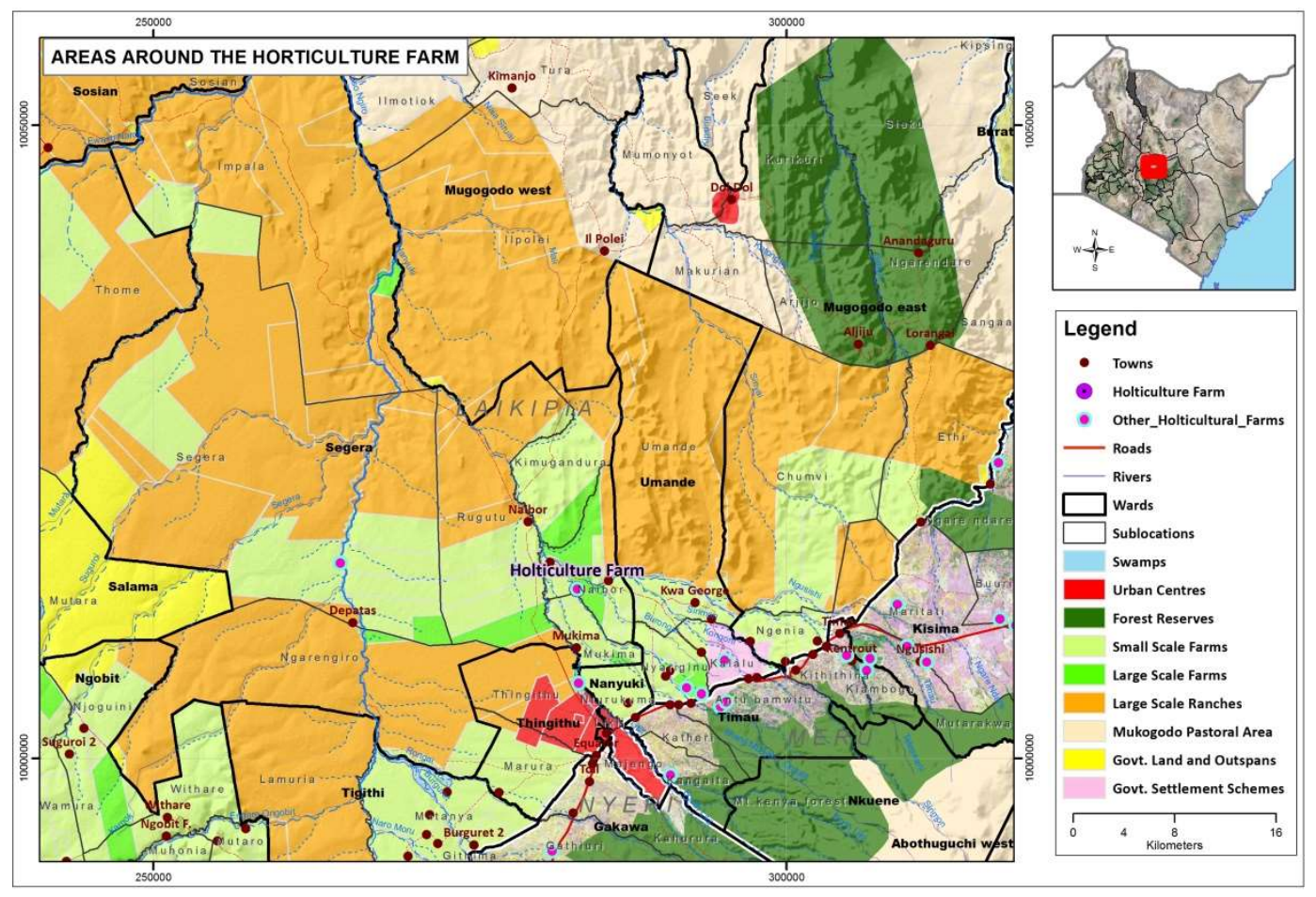

Figure 1 Map of the study area (Source: CETRAD)

The horticulture farm is the first of three farms owned by a horticulture investment with headquarters in Nairobi that exports fresh fruits and vegetables to the United Kingdom (U.K.) since the 1970's. The investment in Northwest Mount Kenya comprises a farm and onsite packhouse. Production is an all year round activity in large-scale horticulture farming except in seasons of drought and water scarcity. The climate in Northwest Mount Kenya varies from humid to semi-humid on the mountain slopes and semi-humid to semi-arid on the lowlands. The area experiences erratic rainfalls with a precipitation of $450-700 \mathrm{~mm}$ per annum with prolonged dry spells. The level plateau and the entire county drainage are dominated by the 
Ewaso Nyiro North basin with its tributaries which have their sources in the slopes of the Aberdares and Mt. Kenya and flow from South to North (GOK 2013). The flow of these rivers matches the topography which slopes gently from the highlands in the South to the lowlands in the North. The rivers determine to a large extent the settlement patterns, as they are a source of water for human and livestock consumption as well as irrigation activities (GOK 2013).

The export horticulture investments, ranches and wildlife conservancies have also notable presence in the region with large tracts of land fenced off. They increase their water accessibility through the drilling of boreholes and rainwater harvesting and storage. There are 30 export horticulture investments operating on 35 farms and covering an area of 1385 hectares in Northwest of Mount Kenya (Lanari 2014). The small-scale farmers diversify their crops to include traditional subsistence crops like cereals and tubers and commercial cash crops for both domestic and export markets such as vegetables, herbs and fruits. The farmers gain access to land as private property by inheritance, purchase and lease. The pastoral communities have settled in community group ranches with a few families moving away and settling in their own purchased land but still holding forte in the group ranches.

In seasons of harsh weather and limited water access, the different food systems often compete for the resources with potential for conflict (Lanari et al 2016; Ulrich 2014).

\section{Study design and selection of study participants}

This study adopted an inductive case study design based on in-depth qualitative exploration to establish the institutional setting of export horticulture in Northwest Mount Kenya region in relation to common pool resources. The study adopted a qualitative approach to allow for emic perspectives of the food system actors. Study participants were purposively sampled, taken through the informed consent process and verbal consent obtained with emphasis made 
on the participant's right of voluntarism in deciding whether or not to participate in the study. ${ }^{1}$

\section{Fieldwork and data analysis}

Data was collected through triangulation of different qualitative methods (in-depth and key informant interviews, observations and focus group discussions) to enhance data validity and reliability. Qualitative interviews were carried out at a time and place convenient to the study participants with consideration for their work demands. Observations were on-going for the entire study period. The qualitative data obtained through the in-depth interviews, key informant interviews, focus group discussions and field notes compiled from observations was inductively coded and thematic analysis applied. Verbatim quotations were used to present information provided by the informants in retrospect. Ethical considerations were applied to data collection and subsequent analysis. ${ }^{1}$

\footnotetext{
${ }^{1}$ Ethical considerations

The approval and permit for this study were issued by the National Council of Science, Technology and Innovation (NACOSTI), Kenya. Collaboration and approval was further sought from the Export horticulture investment, county government education and agriculture offices. The participants were given full details of the study including any fore seen or anticipated risks and how to tackle them in case they occurred, and any benefits / compensations or lack of beforehand. Informed consent and permission to record interviews was obtained.
} 


\section{Acknowledgements}

The export horticulture farm and packhouse management and workers, small-holder farmers, county and national government representatives in North West Mount Kenya were part of this study. Your approval to carry out the study, hosting and engaging the researcher and your invaluable insights made this study possible. Thank you very much

\section{Author contributions:}

I, Mariah Ngutu Peter, a Ph.D. candidate from the University of Nairobi, identified the research site, recruited the informants, collected and analysed the data. I drafted the original manuscript and have been working closely with my supervisors also co-authors in this paper to review and edit the paper for submission to the journal of Land.

Dr. Salome Bukachi was my first supervisor from the initial conceptualization of the study topic to data collection and editing and reviewing of the manuscript. Salome Bukachi is a senior research fellow in Anthropology at the Institute of Anthropology, Gender and African Studies, University of Nairobi.

Prof. Charles Owuor Olungah was my second supervisor from the proposal writing stage to data collection and editing and reviewing of the manuscript. Charles Olungah is a professor of Anthropology at the Institute of Anthropology, Gender and African Studies, University of Nairobi. Moreover, as the director of the Institute of Anthropology, Gender and African studies, he also provided administrative support.

Prof. Tobias Haller is a professor of Anthropology at the University of Bern in Switzerland. As my third supervisor he followed up on the conceptualization of the study, data collection editing and reviewing of the manuscript.

\section{Conflicts of interest: None}

\section{References}

1. Government of Kenya (GoK). Kenya Economic Survey (KES). Kenya National Bureau of Statistics (KNBS): Nairobi, Kenya: 2017.

2. Food and Agriculture Organization of the United Nations (FAO). The State Of Food and Agriculture: Climate Change, Agriculture and Food Security: Rome, Italy: 2016.

3. Colonna P, Stephane F and Jean-Marc T. Food Systems. In M. R. and N. B. Catherine Esnouf(Ed.), Food system sustainability. Insights from DuALIne, Cambridge University Press, UK: 2013: 69-100

4. Haller T, Fokou G, Mbeyale $\mathbf{G}$ and Meroka $P$. How fit turns into misfit and back: Institutional transformations of pastoral commons in African floodplains. Ecology and Society, 2013; 18: 34. https://doi.org/10.5751/ES-05510-180134 
5. Henson $\mathbf{S}$ and Humphrey $\mathbf{J}$. Understanding the Complexities of Private Standards in Global Agri-Food Chains as They Impact Developing Countries Understanding the Complexities of Private Standards in Global Agri-Food Chains as They Impact Developing Countries. The Journal of Development Studies, 2010; 46:1628-1646. https://doi.org/10.1080/00220381003706494

6. Government of Kenya (GoK). Agriculture, Livestock and Fisheries Authorities (AFFA). Horticulture Validated Report: Nairobi, Kenya: 2014

7. Ongeri, B. Small Scale Horticultural farming along the Kenyan Highways and Local economic development : Exploring the effect of factor prices. International Review of

8. Ulrich A. Assessing the Implications for Rural Livelihoods. Sustainability, 2014; 6: 336-347. https://doi.org/10.3390/su6010336

9. MacGregor J, Nordin A and Stage J. Strategic Alliances in Kenyan Smallholder Farming. Poslovna Izvrsnost/Business Excellence, 2014; 8: 49-64. Retrieved from: http://hrcak.srce.hr/poslovnaizvrsnost?lang=en\%5Cnhttp://search.ebscohost.com/login.as px?direct $=$ trueanddb $=$ ecnandAN $=1464373$ andsite $=$ ehost-live

10. Ouma S. Global Standards, Local Realities : Private Agrifood Governance and the Restructuring of the Kenyan Horticulture Industry. Economic Geography, 2010; 86: 197222

11. CARE. Political Economy Analysis of Kenya' s Horticultural sector: iinterests and motivations in Kenya's horticultural sector effecting outcomes and impacts CARE Kenya's target groups with specific focus on product value chain 2016: UKaid. https://doi.org/10.1093/oxfordhb/9780199560103.003.0005

12. Schuler R. Commercial Horticulture North-West Of Mt. Kenya, 2004. University of Berne.

13. Lanari N, Liniger H, and Boniface K. Commercial Horticulture in Kenya: Adapting to Water Scarcity. CDE Policy Brief, 2016; 8.

14. Dolan $\mathbf{C}$ and Humphrey J. Changing governance patterns en the trade in fresh vegetables betwen Africa and the United Kingdom. Environment and Planning, 2004;36:491-509. https://doi.org/10.1068/a35281

15. Asfaw S, Mithöfer D and Waibel H. What impact are EU supermarket standards having on developing countries' export of high-value horticultural products? Evidence from Kenya. Journal of International Food and Agribusiness Marketing, 2010; 22: 252-276. https://doi.org/10.1080/089744331003641398

16. Ensminger, J. (1998). Anthropology and the New Institutionalism. Journal of Institutional and Theoretical Economics. https://doi.org/10.2307/40752112

17. Zaehringer J, Wambugu G, Kiteme B, and Eckert S. How do large-scale agricultural investments affect land use and the environment on the western slopes of Mount Kenya? Empirical evidence based on small-scale farmers perceptions and remote sensing. Journal of Environmental Management, 2018; 213:79-89.

https://doi.org/10.1016/j.jenvman.2018.02.019

18. Ali, J.,and Kapoor, S. Farmers' Perception on Risks in Fruits and Vegetables Production : An Empirical Study of Uttar Pradesh \&. Egricultural Economics Research Review, 2008; 21, 317-326.

19. Anseeuw, W., Wily, L. A., Cotula, L., and Taylor, M. (2011). Land Rights and the Rush for Land. ILC Rome report. Retrieved from http://www.landcoalition.org/en/resources/land-rights-and-rush-land

20. Lanari N, Liniger H, and Boniface K. Commercial Horticulture in Kenya: Adapting to Water Scarcity. CDE Policy Brief, 2016; 8.

21. Government of Kenya (GoK). County Integrated Development Plan (CIPD). Laikipia County Integrated Development Plan (2013-2017), 2013: Nairobi, Kenya 
22. Ferguson, J.The Anti Politics Machine.pdf. Ecologist, 1994; 24(5), 176-181.

23. De Schutter, $\mathbf{O}$. How not to think of land-grabbing: Three critiques of large-scale investments in farmland. Journal of Peasant Studies, 2011;38(2), 249-279. https://doi.org/10.1080/03066150.2011.559008

24. Borras, S. J. M., Hall, R., Scoones, I., White, B., Borras, S. M., Hall, R., ... Wolford, W. (). Towards a better understanding of global land grabbing: An editorial introduction. Journal of Peasant Studies, 2011; 38(2), 209-216. https://doi.org/10.1080/03066150.2011.559005 